\title{
INTERNATIONAL HANDBOOK OF UNIVERSITIES
}

AND OTHER INSTITUTIONS

OF HIGHER EDUCATION

NINTH EDITION 


\section{COMPANION VOLUMES:}

Commonwealth Universities Yearbook, Joint Editors A. Christodoulou and T. Craig.

ISBN 085143076 7; ISSN 0069-7745. (Association of Commonwealth Universities, John Foster House, 36 Gordon Square, London WC1H OPF).

American Universities And Colleges, Twelfth Edition. ISBN 08992500090.

(Walter de Gruyter for American Council on Education, 1 Dupont Circle, Suite 801, Washington, D.C. 20036.)

Every three years the International Association of Universities also edits the

$$
\text { WORLD LIST OF UNIVERSITIES }
$$

This is a concise directory covering more than 8500 universities and other institutions of higher education throughout the world, including the Commonwealth and the United States of America, and providing information about the principal national and international organizations concerned with higher education. 


\title{
INTERNATIONAL HANDBOOK OF UNIVERSITIES
}

\author{
AND OTHER INSTITUTIONS \\ OF HIGHER EDUCATION
}

NINTH EDITION

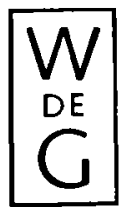


Editor

D. J. AITKEN

Assistant Editor

ANN C. M. TAYLOR

(C) The International Association of Universities 1983

All rights reserved. No part of this publication may be reproduced or transmitted, in any form or by any means, without permission.

Published every three years.

Ninth Edition 1983 by

THE MACMILLAN PRESS LTD

London and Basingstoke, and

WALTER DE GRUYTER

Berlin and New York.

ISBN 3110097435

Printed in Hong Kong 